\title{
Cold supply chain of longline tuna and transport choice
}

Cold supply chain of longline tuna

\author{
Yi-Chih Yang
}

Department of Shipping and Transportation Management, National Kaohsiung University of Science and Technology, Kaohsiung, Taiwan, and

\author{
Han-Yu Lin \\ Taiwan Tuna Association, Kaohsiung, Taiwan
}

\begin{abstract}
Purpose - The four purposes of this study are to understand the development and the current status of Taiwan's far seas longline tuna fisheries through a review of the literature and interviews; to investigate the attitude of Taiwanese fishing vessel operators fishing in the Indian Ocean concerning the use of transportation under the influence of various factors; to analyze the relationship between changes in the transportation behavior of Taiwanese fishing vessel operators and various factors; and to provide suggestions to government and industry associations concerning the development of viable response strategies.

Design/methodology/approach - This paper uses methods including factor analysis and the analytic hierarchy process to analyze questionnaires collected from industry personnel and governmental personnel involved in the supply chain system of the longline tuna fishery in the Indian Ocean.

Findings - It is found that 16 assessment criteria in four major dimensions have major influence on the choice of cold chain transport. An assessment of all dimensions indicates that reefer ships are still the preferred means of transshipping frozen catch.

Originality/value - This paper seeks to investigate factors affecting choice of cold chain mode of transport from the perspective of Taiwanese companies operating longline tuna fishing vessels in the Indian Ocean, which are chiefly motivated by the need to reduce operating costs, and also looks at their choices of means of transport.
\end{abstract}

Keywords AHP, Cold chain, Longline tuna, Modal choice

Paper type Research paper

\section{Introduction}

Fishing is an important primary industry contributing to economic development in many countries, and its importance spans the aspects of economic production, diplomacy, trade, employment, and its role as the main source animal protein for human beings. As a result, fish and fishery products account for the highest proportion of foods in global trade (FAO, 2010). Tuna and tuna-like species have high economic value, and their main markets include sashimi, steaks and canned tuna. Japan is the world's most important consumer of sashimi. According to the 2010 statistics of the United Nations Food and Agriculture Organization (FAO), the six leading tuna fishing countries are Japan, Taiwan, South Korea, France, Spain and China. Following Japan, Taiwan is the second important tuna fishing country in the world (Haward and Bergin, 2000).

Among the far seas fisheries in Taiwan, the longline tuna industry occupies a very significant position with its large scale of operations and highest output value. According to

(c) Pacific Star Group Education Foundation.

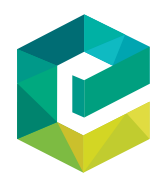

Received 11 November 2017 Revised 26 November 2017 Accepted 28 November 2017 
MABR

2,4

Figure 1.

Catch transshipment statistics for reefer container ships and reefer ships, 20082016 the Taiwan Fisheries Statistical Yearbook 2011, the average output and value of the longline tuna industry had exceeded 217,000 MT and NT\$28.3bn during the previous three years, and these figures represented around 33 per cent of the total far seas fishing output and 65 per cent of the total far seas fishing value in Taiwan (Taiwan Fisheries Agency, 2016). This fishery can be classified as the conventional longline tuna and the super freezer longline tuna fisheries based on the target species and the freezing facilities. The target species of the conventional longline tuna fishery is albacore, which is chiefly supplied to American-owned canneries as the raw material in canned tuna or exported to Europe for use in fish fillets. The refrigeration equipment of the conventional longline tuna vessels can freeze fishes to a temperature of $-35^{\circ} \mathrm{C}$. In the super freezer tuna fishery, the refrigeration equipment of vessels has a freezing capacity of -50 to $-60^{\circ} \mathrm{C}$ and the fishery's catch is mostly sold to Japan for the sashimi market.

After Taiwanese longline tuna fishing vessels have operated in the Indian Ocean for a certain period of time, they will choose to transship their frozen fishes at sea or in port in accordance with the plans of the company. It can be seen from the statistics in Figure 1 that operators have remained heavily dependent on freezer carrier vessels over recent years, and the number of transshipments increased briefly from 690 in 2008 to 564 in 2016 . However, in view of high fuel prices, international regulations, the threat of piracy and other factors, some fishing vessels operating in the Indian Ocean have returned to Kaohsiung, Taiwan, and subsequently shifted to fishing in the Pacific or Atlantic Ocean. From 2010 to 2016, some operators have preferred to transship their catches to reefer container ships in port.

Figure 2 shows that 75 per cent of the reefer container ships used by the longline tuna industry were operated by MAERSK from 2008 to 2016, followed by 11 per cent operated by CMA CGM and 4 per cent operated by APL. The chief reason for this is that only MAERSK and CMA CGM shipping companies have reefer containers of $-60^{\circ} \mathrm{C},-40^{\circ} \mathrm{C},-35^{\circ} \mathrm{C}$ and $-25^{\circ} \mathrm{C}$, and other companies have not any $-60^{\circ} \mathrm{C}$ container with the same capacity. This reason has allowed MAERSK and CMA CGM can monopolize the reefer container market. On the other hand, operators have found that the quality of MAERSK's service has happened to such problems as uneven quality of refrigeration equipment and delayed container delivery sometimes occurs. These drawbacks have caused operators additional

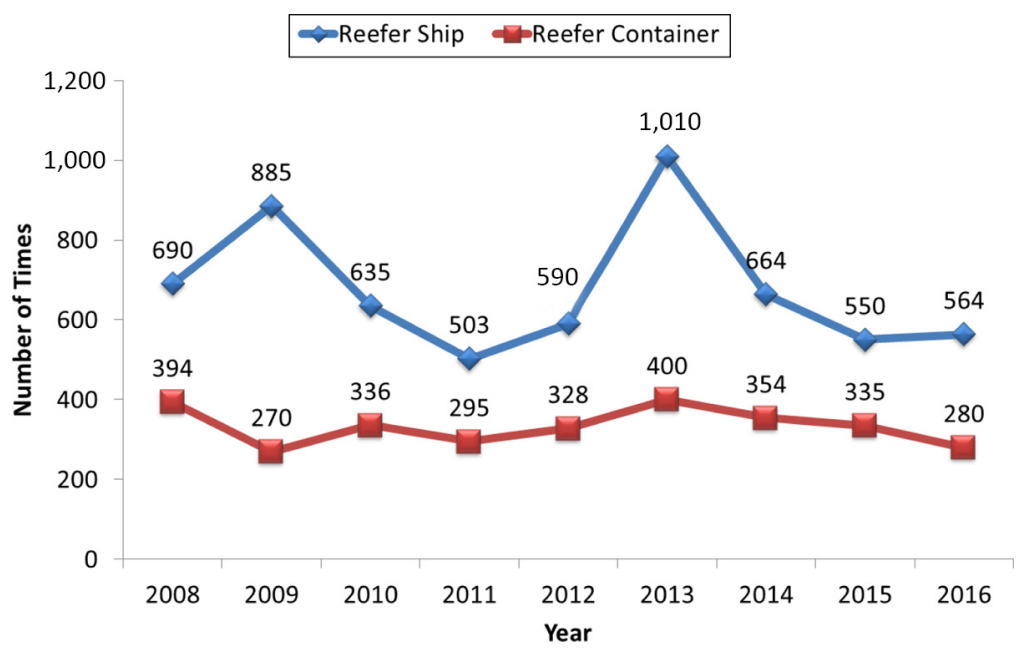




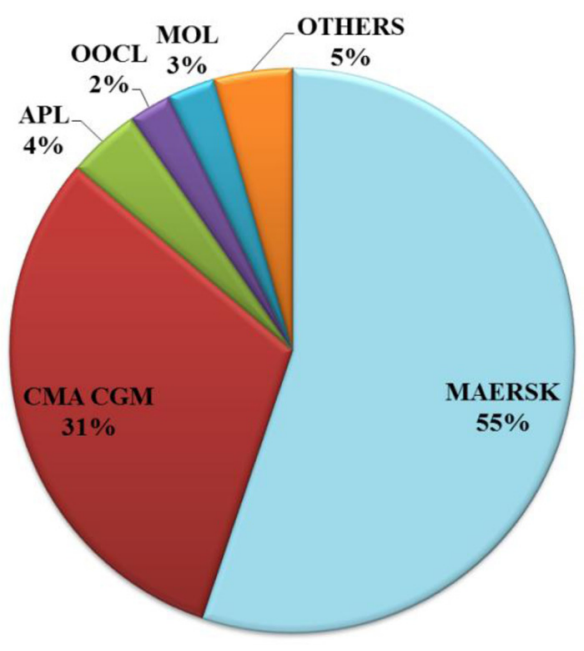

\author{
Cold supply \\ chain of \\ longline tuna
}

351

costs and even damage to the catch. According to the experience of the industry operators, in comparison with the freezer carrier vessels, cryopreservation containers often tend to suffer from temperature problems. Moreover, cryopreservation containers often do not have sufficient quantities, which leads to the problem of late deliveries. As things currently stand, most fishing vessels will, therefore, choose reefer container ships to transship their catches unless the problems of equipment and availability can be solved.

However, with the rapid development of high seas fisheries, numerous countries have found that there is a need to develop fisheries management and conservation mechanisms, and the FAO has consequently adopted the Code of Conduct for Responsible Fisheries and other international protocols for the conservation and management of fishery resources at the international level (Hsueh, 2004). In recent years, due to the restrictive measures adopted by international management organizations, the rising price of oil, as well as the fact that almost 53 per cent of the fisheries stocks are fully exploited and 32 per cent of fisheries stocks are either over-exploited, depleted or recovering from depletion (FAO, 2010). Catches in many fisheries have decreased significantly. Moreover, rising fishery access fees and related costs in coastal states, the threat of Somalian pirates in the Indian Ocean and other business issues have forced many fishing companies with poor cost control to shut down. According to Liu (2011), the far seas longline tuna fishery is an industry with "three highs," namely, high risk, high investment and high technology. In the past, when catches were good, many unreasonable fees and various other derivative costs could be accepted for the sake of convenience. Times have changed, however, and how to control costs has become a major issue directly affecting the development of the far seas longline fishing industry in Taiwan.

It is known that Taiwan's far seas longline tuna industry is currently facing growing competition and pressure in the international environment. According to the FAO (2012), factors affecting fishery trade include production and transportation costs, and shifts in the prices of fishery products and alternative products. In the past, the majority of Taiwanese tuna fishing vessels transshipped their catches by frozen transport ships at sea or by reefer container vessels in port. Nowadays, however, operators cannot freely select their means of transporting their catches. Complex and burdensome policies and economic factors have 
MABR

2,4

\section{2}

Figure 3.

Conceptual map of frozen tuna transshipment options imposed even greater operating cost burdens and influenced the choice of transportation. When operators face new difficulties and challenges, apart from continuing to improve the efficiency of the operation of fishing vessels, operators must also change their refrigerated transport decisions, and this inevitable change forms an important motivation for this study.

This paper seeks to explore factors that may affect the choice of cold chain transportation models from the perspectives of industry operators. As shown in Figure 3, one difference between the transport of far seas longline tuna catch and the transport of other general cargo is that fishing vessels can choose to transfer their catches in port, or at sea to reefer carriers, and can also choose to enter port and use reefer container ships to transport their frozen tuna.

The four purposes of this study are:

(1) to understand the development and the current status of Taiwan's far seas longline tuna fisheries through a review of the literature and interviews;

(2) to investigate the attitude of Taiwanese fishing vessel operators fishing in the Indian Ocean concerning the use of transportation under the influence of various factors;

(3) to analyze the relationship between changes in the transportation behavior of Taiwanese fishing vessel operators and various factors; and

(4) to provide suggestions to government and industry associations concerning the development of viable response strategies for the far seas longline tuna industry and reference information for use in negotiations.

\section{Cold chains}

According to the International Refrigeration Dictionary, which was published by the International Institute of Refrigeration (2008), "cold chain" is defined as the use of cryopreservation to preserve perishable products through successive stages extending from the start of production to final consumption. The Cold Chain Association (2013) considers a cold chain to be an entire supply chain throughout the stages of production, storage and distribution of goods, where a certain degree of temperature control is required to maintain the characteristics of products. This study considers that a cold chain refers to the product process from the beginning of production to the end user when the entire transport process must be subject to temperature control to avoid damage or destruction of product quality.

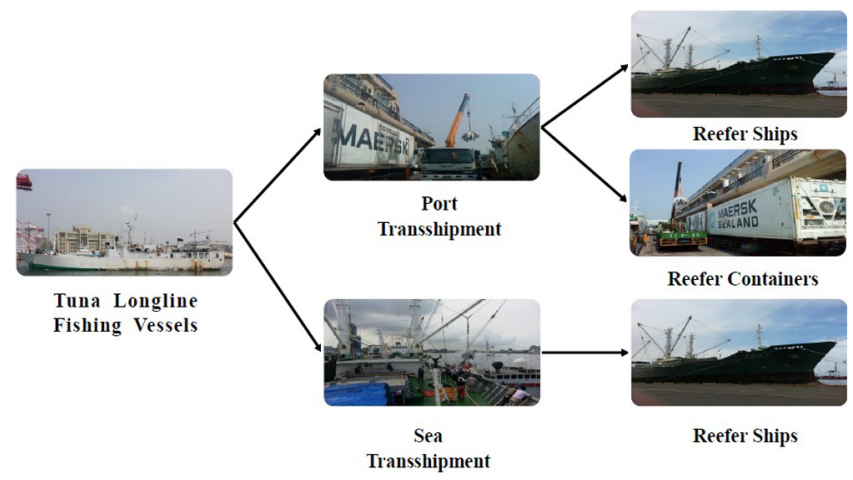


How to maintain the temperature throughout the entire refrigerated supply chain is the crucial element that forms the basis of all cold chains, and is the most difficult issue to resolve in the development of a cold chain.

\subsection{Development of ultra-low temperature frozen foods}

As economic and living standards are going up, the quality requirements for tuna sashimi have also continued to increase. Low-temperature freezing is the only effective way to prevent spoilage of fishery products and ensure that the taste and color requirements are met. This need has driven the development of ultra-low-temperature refrigeration systems. In the early days, coastal tuna fishing boats would fill their fish tanks with crushed ice to prevent spoilage of their catch and keep the fish fresh; this is called the "ice refrigeration method." However, this method can only attain temperatures near the freezing point. It can preserve the freshness of fish for only a limited amount of time that is typically one-two weeks. As more and more distant fishing zones had developed, fishing vessels began to rely on the use of freezers. This freezing method can attain temperatures ranging from the freezing point to $-5^{\circ} \mathrm{C}$. It is sufficient to kill bacteria, stop biochemical reactions in fishes, and prevent spoilage of fishes. Nevertheless, this method can merely prevent spoilage of fishes. It cannot preserve the original freshness, taste and color of fishes. To further improve the quality of tuna, complete freezing is necessary.

The longline tuna industry in Taiwan has largely inherited the Japanese technology. To ensure that tuna is kept as fresh as when it was first caught, freezing technology has to make breakthroughs and improvements continuously (Hsueh, 2004). As shown in Table I, from 1950 until present, the freezer compartments of fishing boats and the cold storage warehouses in which fishes are stored have continuously improved their storage environment. Nowadays, after the catches have been undergone simple pre-processing, they are placed in a rapid freezing chamber at a temperature of $-60^{\circ} \mathrm{C}$ to $-65^{\circ} \mathrm{C}$. The fishes begin to freeze at a temperature of around $-2^{\circ} \mathrm{C}$, and freeze completely when its core temperature has fallen to $-50^{\circ} \mathrm{C}$. The fishes are then passed through cold water to cause a thin layer of ice to be formed on fishes. The ice layer serves to protect the fishes by cutting off the contact from the air. The fishes are finally moved to a storage hold at a temperature of -55 to $-60^{\circ} \mathrm{C}$. Chow (1989) points out that, while tuna is frozen at a temperature of -10 to $-20^{\circ} \mathrm{C}$, it will turn brown at an accelerating rate, i.e. from freezing to a temperature of $-60^{\circ} \mathrm{C}$. Storage at a temperature of under $-60^{\circ} \mathrm{C}$ is an ideal situation to prevent changes and deterioration of tuna. To be able to transport frozen tuna fish and other aquatic products in the best conditions,

\begin{tabular}{lrr}
\hline & Far seas longline tuna vessel refrigeration equipment temperature & \\
Period & Freezer compartment & Fish warehouse \\
\hline $1950 \sim 1955$ & $-25 \sim-30^{\circ} \mathrm{C}$ & $-15 \sim-20^{\circ} \mathrm{C}$ \\
$1955 \sim 1960$ & $-30 \sim-35^{\circ} \mathrm{C}$ & $-20 \sim-35^{\circ} \mathrm{C}$ \\
$1960 \sim 1965$ & $-35 \sim-40^{\circ} \mathrm{C}$ & $-25 \sim-30^{\circ} \mathrm{C}$ \\
$1965 \sim 1968$ & $-40 \sim-45^{\circ} \mathrm{C}$ & $-35 \sim-40^{\circ} \mathrm{C}$ \\
$1968 \sim 1970$ & $-45 \sim-50^{\circ} \mathrm{C}$ & $-40 \sim-45^{\circ} \mathrm{C}$ \\
$1970 \sim 1972$ & $-50 \sim-55^{\circ} \mathrm{C}$ & $-45 \sim-50^{\circ} \mathrm{C}$ \\
$1972 \sim 1980$ & $-55 \sim-60^{\circ} \mathrm{C}$ & $-50 \sim-55^{\circ} \mathrm{C}$ \\
After 1980 & $-60 \sim-65^{\circ} \mathrm{C}$ & $-55 \sim-60^{\circ} \mathrm{C}$
\end{tabular}

Source: Watanabe (1991)

Cold supply chain of longline tuna

353 . 
MABR

2,4

Figure 4.

Frozen tuna supply chain frozen and reefer container transport ships are gradually adopting ultra-low-temperature freezer technology which can ensure the catches to be preserved during transportation.

\subsection{Overview of the frozen tuna supply chain}

Tuna is one of Japan's favorite types of fish, and most tuna are eaten in the form of sashimi in Japan (Sakai et al., 2007). According to the FAO, Japan accounts for almost all of the frozen tuna sashimi market. Japanese-owned tuna fishing vessels account for the catch of slightly over 200,000 tons of tuna consumed domestically, and roughly another 400,000 tons have to be imported to Japan (Miyake, 2010). Due to the fact that the freshness of tuna needed for sashimi can be maintained through refrigerated transport, Japan serves as the final market for almost the entire frozen tuna supply chain. After processing on far seas longline tuna vessels operating offshore, frozen tuna can be transported to Japan by fishing vessels, reefer ships and reefer container ships. The current frozen tuna supply chain consists of two models, as shown in Figure 4:

(1) Domestic: Tuna caught by domestic longliners is unloaded at a home port and immediately placed in storage. The fish unloaded at landing port markets can be sold locally through auctions, or prepared and sent to central markets. Some are sold directly to buyers or wholesalers, and sometimes to large-scale retailers.

(2) Imported: Tuna caught by foreign fishing vessels (such as Taiwan, South Korea, China and others) is unloaded from transshipment reefer ships or reefer container ships into ultra-low-temperature frozen storage areas by importers. These largescale importers buy fishes directly from fishing vessels. Most of the tuna kept in cold storage by the buyers or traders is sold directly to large-scale retailers, including chain retailers and supermarkets.

\subsection{Cold chain transport methods}

According to Dellacasa (1987), the maritime transport of refrigerated goods consisting of the transport of perishable foods from the producers to the consumers is an important part of cold chain transport. While there are many types of cold chain transports, this paper examines only the main modes of transport for bulk frozen seafood, and thus the land and air transports are not discussed in this paper. Transports of frozen tuna and tuna-like species can generally be classified as three types, namely, far seas longline tuna vessels,

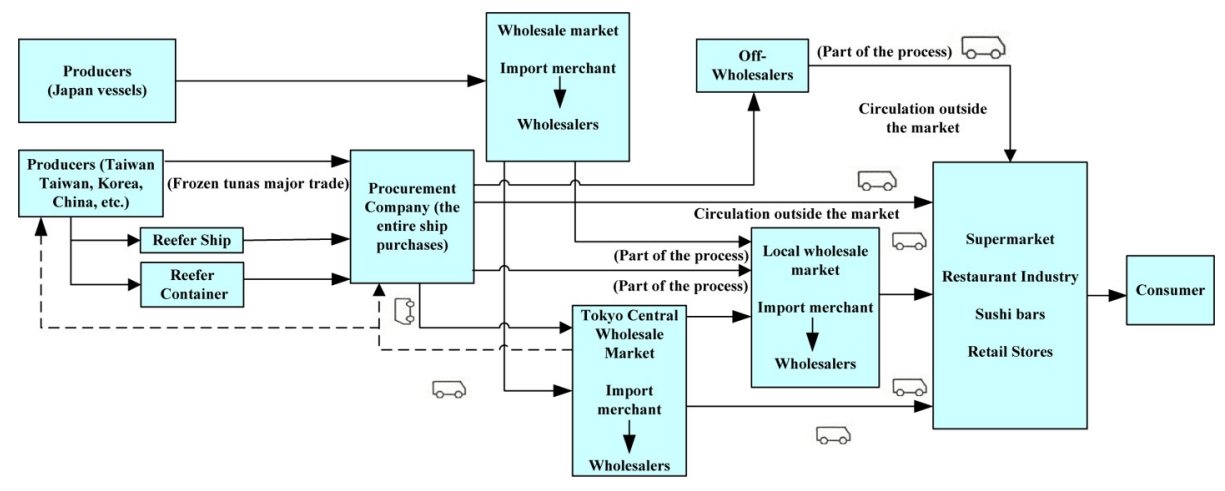

Source: Watanabe (1991) and Tsudani (1998) 
reefer ships and reefer container ships. The following is a summary of these modes of transportation:

2.3.1 Longline tuna fishing vessels. According to the Fishing Operations report 1996 issued by the FAO (2010), any vessel used or intended to be used for commercial exploitation of living marine resources, including mother ships and other vessels directly engaged in fishing operations, can be called "fishing vessels". Powered fishing vessels engaged in fishing operations outside the 200-nautical-mile economic zone of Taiwan, including those operating in the economic zones of other countries are known as "far seas fishing vessels". The longline fishing method generally involves many branch lines installed on a main line, with a baited hook at the end of each branch line, and the bait most commonly consisting of squid, Pacific saury, mackerel and sardines, etc. Fishing vessels using this fishing method are known as "longline fishing vessels".

2.3.2 Reefer ships or refrigerated cargo carriers. Reefer ships are designed to carry perishable products requiring temperature control and must therefore have cargo refrigeration systems. Most reefer ships are used to carry fishes, fruits, vegetables, meats and dairy products, etc. Vessels which used to transport fish consist of live fish transport vessels and reefer ships. Since the development of reefer ships, they have helped to improve productivity of far seas longline tuna vessels. As fish can be transshipped at sea to consumer countries at an early date, reefer ships can improve fisheries management, reduce capacity problems and lessen the spoilage of catch due to loss of temperature control.

2.3.3 Reefer container ships. Reefer container ships carry cargo containers that have refrigeration equipment. The invention of refrigerated containers has enabled perishable products to be transported to distant places while maintaining their characteristics intact. The first use of reefer container ships was by Sea-Land, an American shipping company, in 1956. The vessels have since brought about a historic change in cargo transport and trade (Branch and Stopford, 2013). In terms of functions, reefer container ships can be classified as standard reefer container ships, gas control container ships, ultra-low-temperature reefer container ships and extremely-low-temperature cargo containers ships. Ultra-lowtemperature reefer container ships can export tuna to Japan for sashimi at an ultra-low temperature of $-60^{\circ} \mathrm{C}$. For $-25^{\circ} \mathrm{C}$ and $-35^{\circ} \mathrm{C}$ reefer container ships, they can transport tuna for canning or uses other than as sashimi. As tuna has high economic value, the temperature problem may lead to an entire container of frozen tuna sashimi to become inedible. As a consequence, a container company or shipping company may send personnel to perform random testing of fish temperature ensuring that tuna has reached the standard ultra-low temperature, and avoiding the possibility of disputes (Figure 5).

Chen and Notteboom (2012) proposed that freezer vessels offer the advantages of shorter transport time and better temperature control, while reefer container ships offer lower transport costs and easier in-port transshipment. This study relied on the literatures and interviews to compile the operating advantages of the three commonly used modes of frozen tuna transport. However, fishing vessels are included for comparison purposes only, as tuna is very seldom unloaded directly from fishing vessels in Japan. As shown in Table II, the transshipment time of freezer carrier vessels have advantages enabling higher capital turnover rate, lower temperature risk, higher loading capacity, better mobility and other advantages. In contrast, reefer container ships offer low transport costs, no fuel costs and international control. While it can be seen why freezer carrier vessels are preferred by operators, in the wake of changes in the international environment, transport costs, fuel costs and the need for international control are causing operators to consider the use of reefer container ships.
Cold supply chain of longline tuna

355 


\section{MABR}

2,4

\section{Figure 5.}

Tuna temperature

detection

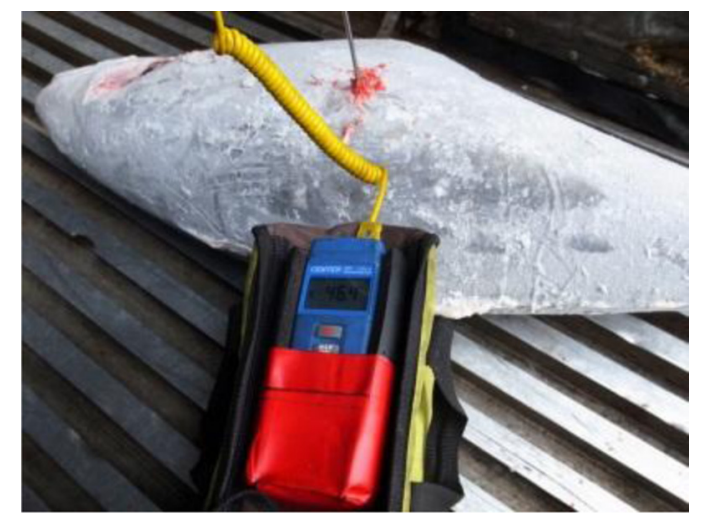

Table II.

Comparison of cold chain transport mode advantages

\begin{tabular}{llll}
\hline Type item & Longline vessels & Freezer carriers & Reefer container vessels \\
\hline Transportation costs & - & Higher & Lower \\
Transport time & Normal & Short & Long \\
Capital turnover rate & Low & Higher & Lower \\
Fuel costs & High & Higher & \\
Temperature risk & Normal & Lower & Higher \\
Loading & Normal & Higher & Lower \\
Flexibility & Good & Better & Lower \\
International control & Much & More & Less
\end{tabular}

Source: Chen and Notteboom (2012) and expert interviews

\section{Methodology}

This study first sought to understand and analyze issues facing the industry, and then compile a questionnaire through interviews with experts in the industry. Finally, factor analysis and AHP analysis were used to analyze the factors affecting the choice of transport modes.

\subsection{Factor analysis and the analytic hierarchy process}

Factor analysis consists of a series of methods for identifying clusters of related variables, and is therefore an ideal technique for reducing numerous items into a more easily understood framework. Factor analysis involves the use of a data matrix produced from numerous individual cases or respondents.

The analytic hierarchy process (AHP) is most applicable to problems with unclear or multi-faceted standards. AHP involves collection of opinions from experts and managers, use of a nominal scale to perform pair-wise comparisons between factors, establishment of a pair comparison matrix and calculation of eigenvectors and eigenvalues. Eigenvectors display the rank of factors on one level and enable the evaluation of the relative weight of every indicator in a model. Furthermore, AHP can be used to analyze the consistency of a matrix by using a consistency index and consistency ratio to evaluate the level of consistency among the experts. Owing to the advantages of simplicity and easy operating 
procedures, AHP is able to collect opinions of many experts at the same time and is considered one of the most optimal decision-making techniques.

After a hierarchy framework is established, pair-wise comparisons are performed between each layer's decision factors. Taking upper layer factors as decision criteria, the relative importance of each pair of factors is then evaluated. If there are $N$ factors, an $n(n-1) / 2$ pair-comparison matrix is made. Pair comparison of decision factors is used to create a comparative factor matrix, where $a_{i j}$ represents the results of the decision makers' pair-wise comparison of decision factor $i$ and decision factor $j$, which expresses the decision makers' degree of emphasis on each factor (Saaty, 1980).

\subsection{Questionnaire design}

With regard to the design of the two questionnaires in this paper, the first questionnaire sought to gather basic information, which included age, position, number of employees and job seniority. A Likert scale extending from 1 (extremely unimportant) to 7 (extremely important) was used in the design of the questionnaire. To determine the structure of the questionnaire, in addition to performing a review of fishing literature, interviews were conducted with personnel at the Indian Ocean longline tuna vessel operating companies.

The second questionnaire used the dimensions and assessment criteria determined also using in the first questionnaire. AHP was then used to assess the impact of the assessment criteria on cold chain transport mode choice. In accordance with Saaty (1980) and other studies, the maximum level of assessment factors on each level should not exceed seven, and three to five factors is appropriate in most research.

As for the subjects of the two questionnaire surveys, the first questionnaire was given to 70 fishing companies engaging in longline tuna vessel operations in the Indian Ocean. The subjects of the second questionnaire survey consisted of 25 persons affiliated with the Indian Ocean longline tuna fishing boat operators, industry associations, shipping companies transporting frozen catch and the Fisheries Administration, Council of Agriculture, which is the competent authority in charge of fisheries in Taiwan.

\subsection{Selection factors for cold chain modes of transport}

As there is little past literature concerning selection of cold chain transport modes, the majority of impact factors were acquired from personal interviews with experts at various tuna fishing companies at the port of Kaohsiung.

The total of 16 cold chain mode selection factors comprised:

(1) fishing vessel operating location;

(2) fishing season;

(3) annual maintenance schedule;

(4) reefer ship compliance;

(5) level of transshipment costs;

(6) changes in annual catch quotas;

(7) changes in the market price of fish;

(8) refer container vessel schedules;

(9) international management organization regulatory restrictions;

(10) Regional Observer Program impact;

(11) reduction in fishing grounds;
Cold supply chain of longline tuna 

MABR
(12) rampant Somalian piracy;
2,4
(13) amount of fishing catch;
(14) catch load capacity;
(15) labor shortages; and
(16) fishing vessel resources.

\section{8}

\section{Results}

\subsection{First questionnaire data and statistics}

The first questionnaire was completed by people who were operating large-scale longline tuna fishing vessels in the Indian Ocean in Taiwanese companies; 70 valid samples were obtained from the 70 questionnaires, which represented a 100 per cent recovery rate. The basic information gathered by this questionnaire can be summarized as follows:

- Most of the participants were between 36 to 45 years of age (77 per cent).

- Most had been employed for from 16 to 25 years (67 per cent).

- Most held the job title of shipping manager (64 per cent) (see Table III).

\subsection{Factor analysis}

Factor analysis can be used to derive a relatively small number of factors, which in turn can be used to represent relationships among sets of many interrelated variables. According to the KMO decision criteria proposed by Kaiser (1974), an acceptable value for the KMO test was greater than 0.5. The results indicated a KMO value of sampling adequacy of 0.817 , which was deemed appropriate for analytical purposes. The first stage of factor analysis consisted of determining the strength of the correlation among the 16 factors as determined by the correlation coefficients of each pairs of factors. A matrix was generated automatically using SPSS software. The factor groupings based on varimax rotation are presented and

\begin{tabular}{lcrr}
\hline Basic information & Characteristics & Frequency & $(\%)$ \\
\hline Age & $41 \sim 45$ & 22 & 31.42 \\
& $36 \sim 40$ & 16 & 22.85 \\
& $46 \sim 50$ & 16 & 22.85 \\
& $31 \sim 35$ & 9 & 12.85 \\
& $56 \sim 60$ & 5 & 7.14 \\
Years of seniority & $51 \sim 55$ & 2 & 2.85 \\
& $16 \sim 20$ & 31 & 44.28 \\
& $21 \sim 25$ & 16 & 22.85 \\
Number of employees in company & $11 \sim 15$ & 10 & 14.28 \\
& $6 \sim 10$ & 8 & 11.42 \\
& 26 or more & 5 & 7.14 \\
Job title & 200 or more & 32 & 45.71 \\
& $151 \sim 175$ & 17 & 24.28 \\
& $51 \sim 75$ & 11 & 15.71 \\
& $76 \sim 100$ & 8 & 11.42 \\
& $26 \sim 50$ & 2 & 2.85 \\
& Shipping manager & 45 & 64.28 \\
& General staff & 12 & 17.14 \\
& President & 11 & 15.71 \\
& General manager & 2 & 2.85 \\
\hline
\end{tabular}

Profile of respondents
President
General manager 
reveal that the four components account for 78.82 per cent of the sample variance. As shown in Table IV, four components with eigenvalues greater than 1 were extracted. Each of the factors belonged to only one of the components, with the value of factor loading exceeding 0.5. To make them more meaningful, the four components were renamed:

(1) fishing vessel operating strategies;

(2) fishing vessel operating costs;

(3) international business environment; and

(4) fishing vessel operating efficiency.

With regard to reliability analysis, Cronbach's alpha ranged from 0.78 to 0.94 . A review of literature concerning reliability revealed that a reliability coefficient of 0.70 or higher is considered satisfactory. With regard to validity analysis, the proposed independent variables and items included in each variable were finalized based on suggestions from the respondents, which improved the content validity.

\subsection{Impact of assessment criteria on cold chain transportation choices}

Using data from the first questionnaire, a hierarchical analysis was performed of the four main dimensions:

(1) international business environment;

(2) fishing vessel operating costs;

\begin{tabular}{|c|c|c|c|c|c|c|}
\hline Main factors & Assessment criteria & $\begin{array}{l}\text { Load } \\
\text { factor }\end{array}$ & Eigenvalue & $\begin{array}{c}\text { Cumulative } \\
\text { explained } \\
\text { variation (\%) }\end{array}$ & Cronbach's $\alpha$ & \\
\hline \multirow{4}{*}{$\begin{array}{l}\text { Fishing vessel } \\
\text { operating } \\
\text { strategies }\end{array}$} & $\begin{array}{l}\text { Fishing vessel operating } \\
\text { location }\end{array}$ & 0.916 & \multirow[t]{4}{*}{3.734} & \multirow[t]{4}{*}{23.34} & \multirow[t]{4}{*}{0.942} & \\
\hline & Fishing season & 0.906 & & & & \\
\hline & $\begin{array}{l}\text { Annual maintenance } \\
\text { schedule }\end{array}$ & 0.901 & & & & \\
\hline & Reefer ship compliance & 0.895 & & & & \\
\hline \multirow{4}{*}{$\begin{array}{l}\text { Fishing vessel } \\
\text { operating costs }\end{array}$} & Level of transshipment costs & 0.942 & \multirow[t]{4}{*}{3.395} & \multirow[t]{4}{*}{44.56} & \multirow[t]{4}{*}{0.917} & \\
\hline & $\begin{array}{l}\text { Changes in annual catch } \\
\text { quotas }\end{array}$ & 0.887 & & & & \\
\hline & $\begin{array}{l}\text { Changes in the market price } \\
\text { of fish }\end{array}$ & 0.876 & & & & \\
\hline & $\begin{array}{l}\text { Reefer container vessel } \\
\text { schedules }\end{array}$ & 0.865 & & & & \\
\hline \multirow[t]{4}{*}{$\begin{array}{l}\text { International } \\
\text { business } \\
\text { environment }\end{array}$} & $\begin{array}{l}\text { International management } \\
\text { organization regulatory } \\
\text { restrictions }\end{array}$ & 0.869 & \multirow[t]{4}{*}{3.004} & \multirow[t]{4}{*}{63.33} & \multirow[t]{4}{*}{0.866} & \\
\hline & $\begin{array}{l}\text { Effect of Regional Observer } \\
\text { Program }\end{array}$ & 0.848 & & & & \\
\hline & $\begin{array}{l}\text { Reduction in Fishing } \\
\text { grounds }\end{array}$ & 0.837 & & & & $\begin{array}{r}\text { Table IV. } \\
\text { Summary of factor }\end{array}$ \\
\hline & Rampant Somalian piracy & 0.731 & & & & $\begin{array}{r}\text { analysis of } \\
\text { assessment criteria }\end{array}$ \\
\hline \multirow{3}{*}{$\begin{array}{l}\text { Fishing vessel } \\
\text { operating } \\
\text { efficiency }\end{array}$} & Amount of catches & 0.865 & \multirow[t]{3}{*}{2.479} & \multirow[t]{3}{*}{78.82} & \multirow[t]{3}{*}{0.785} & $\begin{array}{l}\text { assessment criteria } \\
\text { for cold chain }\end{array}$ \\
\hline & $\begin{array}{l}\text { Catch load capacity } \\
\text { Labor shortages }\end{array}$ & $\begin{array}{l}0.829 \\
0.575\end{array}$ & & & & transport mode \\
\hline & Fishing vessel resources & 0.534 & & & & selection \\
\hline
\end{tabular}

Cold supply chain of longline tuna

\section{洒}




\section{MABR}

2,4

\section{0}

Figure 6.

Impact of assessment criteria on cold chain transport choices
(3) fishing vessel operating strategies; and

(4) fishing vessel operating efficiency, and the 16 assessment criteria:

- fishing vessel operating location;

- fishing season;

- annual maintenance schedule;

- reefer ship compliance;

- level of transshipment costs;

- changes in annual catch quotas;

- changes in the market price of fish;

- reefer container vessel schedules;

- international management organization regulatory restrictions;

- effect of the Regional Observer Program;

- reduction in fishing ground;

- rampant Somalian piracy;

- amount of catches;

- catch load capacity;

- labor shortages; and

- fishing vessel resources (Figure 6).

\subsection{Analysis of basic data from the second questionnaire}

The second questionnaire was administered to people who were affiliated with longline tuna fishing boat operators, Tuna Association, reefer ship operators and the Fisheries Administration, Council of Agriculture. This survey was implemented through emails and in-person interviews conducted by the authors; 28 valid samples were obtained from the 28 questionnaires, which represent a 100 per cent recovery rate. As three questionnaires did not

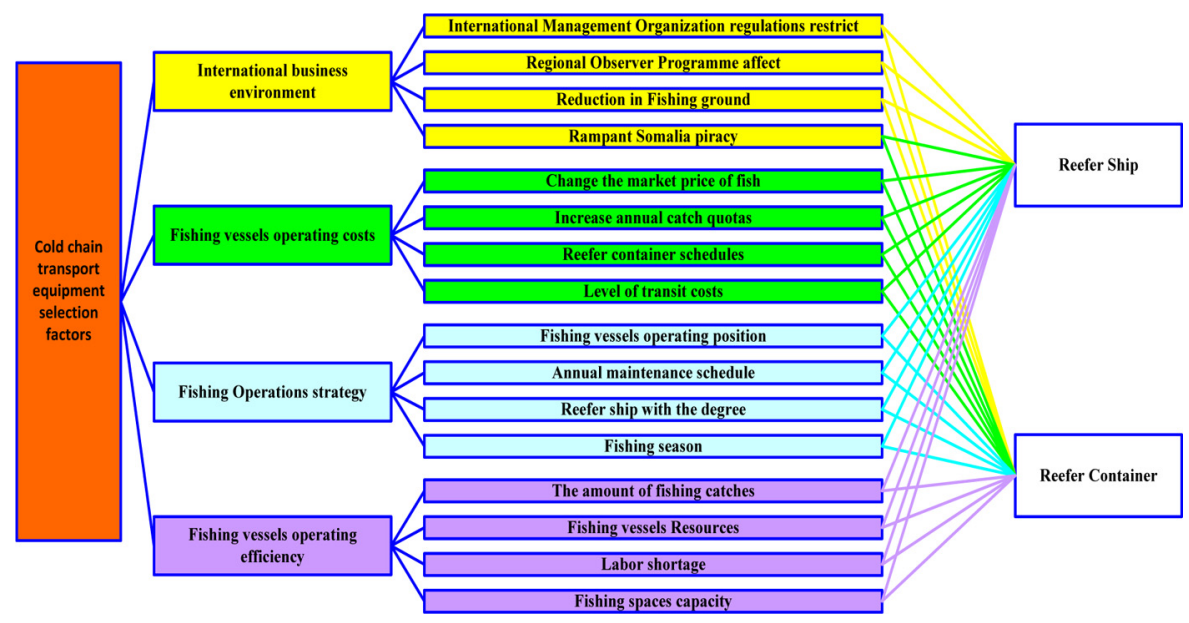


pass the consistency test $(C . R . \leq 0.01)$, there was a final total of 25 valid questionnaires. The basic respondent data obtained from this questionnaire are summarized as follows:

- Most respondents had seniority of from 11 to 20 years (68 per cent).

- Most had a job title of manager (60 per cent).

4.4.1 AHP analysis. Analysis of the AHP expert questionnaire was performed using Expert Choice software to calculate the weight value and implement consistency testing. Following assessment of the weighting results for the four dimensions and 16 assessment criteria, the fact that the C.I. and C.R. values were less than the 0.1 recommended by Saaty (1980) indicated that the valid questionnaires possessed consistency.

Table V shows that all the experts agreed that "Fishing vessels' operating costs" had the greatest impact on choice of cold chain transportation options, and was followed by "Fishing vessel operating efficiency," "International business environment" and "Fishing Operations strategy."

See Table VI for the experts' weighting analysis of factors influencing cold chain transport mode decisions on the second level.

- amount of catches;

- changes in the market price of fish;

- fishing vessel operating location;

- level of transshipment costs;

- international management organization regulatory restrictions;

- rampant Somalian piracy;

- changes in annual catch quotas; and

- catch load capacity.

It can be seen from Table VII that the experts still consider reefer ships to be the preferred means of frozen catch transshipment in view of their assessment of all dimensions. However, among the assessment criteria, Rampant Somalian piracy, level of transshipment costs, annual maintenance schedule and labor shortages tend to make the use of reefer container ships more advantageous.

This result can be understood in the context of today's increasingly difficult fisheries management in the wake of changes in the international environment. According to Chen and Notteboom (2012), while reefer container ships are gradually capturing a share of the market held by reefer ships, the advantages of reefer ships cannot be entirely replaced. The market is, therefore, likely to reach an equilibrium, where reefer ships will provide high-value services and reefer container ships will offer more cost-oriented services.

\begin{tabular}{lcc}
\hline Main factors & Weight & Rank \\
\hline International business environment & 0.201 & 3 \\
Fishing vessel operating costs & 0.326 & 1 \\
Fishing Operations strategy & 0.195 & 4 \\
Fishing vessel operating efficiency & 0.277 & 2
\end{tabular}

Note: All samples passed the consistency ratio $(C . R . \leq 0.01)$

Cold supply chain of longline tuna

361 $-$ 
MABR

2,4

\begin{tabular}{|c|c|c|c|c|c|c|}
\hline \multirow[b]{2}{*}{ Main factors } & \multirow[b]{2}{*}{ Weights } & \multirow[b]{2}{*}{ Sub-factors } & \multicolumn{2}{|c|}{ All experts } & \multicolumn{2}{|c|}{ Overall weight } \\
\hline & & & Weights & Rank & Weights & Rank \\
\hline \multirow[t]{4}{*}{$\begin{array}{l}\text { International } \\
\text { business } \\
\text { environment }\end{array}$} & \multirow[t]{4}{*}{0.201} & $\begin{array}{l}\text { International management } \\
\text { organization regulatory } \\
\text { restrictions }\end{array}$ & 0.352 & 1 & 0.071 & 5 \\
\hline & & $\begin{array}{l}\text { Effect of Regional Observer } \\
\text { Program }\end{array}$ & 0.122 & 4 & 0.025 & 15 \\
\hline & & Reduction in fishing ground & 0.222 & 3 & 0.045 & 11 \\
\hline & & Rampant Somalian piracy & 0.304 & 2 & 0.061 & 6 \\
\hline \multirow[t]{4}{*}{$\begin{array}{l}\text { Fishing vessel } \\
\text { operating costs }\end{array}$} & \multirow[t]{4}{*}{0.326} & $\begin{array}{l}\text { Changes in the market price of } \\
\text { fish }\end{array}$ & 0.461 & 1 & 0.150 & 2 \\
\hline & & $\begin{array}{l}\text { Changes in annual catch } \\
\text { quotas }\end{array}$ & 0.174 & 3 & 0.057 & 7 \\
\hline & & $\begin{array}{l}\text { Reefer container vessel } \\
\text { schedules }\end{array}$ & 0.138 & 4 & 0.045 & 10 \\
\hline & & Level of transshipment costs & 0.227 & 2 & 0.074 & 4 \\
\hline \multirow{4}{*}{$\begin{array}{l}\text { Fishing } \\
\text { Operations } \\
\text { strategy }\end{array}$} & \multirow[t]{4}{*}{0.195} & $\begin{array}{l}\text { Fishing vessel operating } \\
\text { location }\end{array}$ & 0.470 & 1 & 0.092 & 3 \\
\hline & & Annual maintenance schedule & 0.104 & 4 & 0.020 & 16 \\
\hline & & Reefer ship compliance & 0.165 & 3 & 0.032 & 13 \\
\hline & & Fishing season & 0.262 & 2 & 0.051 & 9 \\
\hline \multirow{4}{*}{$\begin{array}{l}\text { Fishing vessel } \\
\text { operating } \\
\text { efficiency }\end{array}$} & \multirow[t]{4}{*}{0.277} & Amount of catches & 0.561 & 1 & 0.155 & 1 \\
\hline & & Fishing vessel resources & 0.149 & 3 & 0.041 & 12 \\
\hline & & Labor shortages & 0.104 & 4 & 0.029 & 14 \\
\hline & & Catch load capacity & 0.186 & 2 & 0.052 & 8 \\
\hline
\end{tabular}

\section{2}

Table VI.

Weights and rank of assessment criteria on the second level operating
efficiency
Table VII.

Overall relative weight and rank of cold chain transport modes

\begin{tabular}{|c|c|c|c|c|c|}
\hline \multirow[b]{2}{*}{ Assessment criteria } & \multirow{2}{*}{$\begin{array}{c}\text { Evaluation } \\
\text { criteria } \\
\text { relative weights }\end{array}$} & \multicolumn{2}{|c|}{$\begin{array}{l}\text { Weights of modes } \\
\text { of transport }\end{array}$} & \multicolumn{2}{|c|}{$\begin{array}{l}\text { Overall weights of } \\
\text { modes of transport }\end{array}$} \\
\hline & & $\begin{array}{l}\text { Reefer } \\
\text { ship }\end{array}$ & $\begin{array}{l}\text { Reefer } \\
\text { container }\end{array}$ & $\begin{array}{l}\text { Reefer } \\
\text { ship }\end{array}$ & $\begin{array}{l}\text { Reefer } \\
\text { container }\end{array}$ \\
\hline \multicolumn{6}{|l|}{ International management } \\
\hline organization regulatory restrictions & 0.071 & 0.674 & 0.326 & 0.048 & 0.023 \\
\hline Effect of Regional Observer Program & 0.025 & 0.588 & 0.412 & 0.014 & 0.010 \\
\hline Reduction in fishing ground & 0.045 & 0.545 & 0.455 & 0.024 & 0.020 \\
\hline Rampant Somalian piracy & 0.061 & 0.423 & 0.577 & 0.026 & 0.035 \\
\hline Changes in the market price of fish & 0.150 & 0.570 & 0.430 & 0.086 & 0.065 \\
\hline Changes in annual catch quotas & 0.057 & 0.571 & 0.429 & 0.032 & 0.024 \\
\hline Reefer container vessel schedules & 0.045 & 0.621 & 0.379 & 0.028 & 0.017 \\
\hline Level of transshipment costs & 0.074 & 0.390 & 0.610 & 0.029 & 0.045 \\
\hline Fishing vessel operating location & 0.092 & 0.749 & 0.251 & 0.069 & 0.023 \\
\hline Annual maintenance schedule & 0.020 & 0.247 & 0.753 & 0.005 & 0.015 \\
\hline Reefer ship compliance & 0.032 & 0.622 & 0.378 & 0.020 & 0.012 \\
\hline Fishing season & 0.051 & 0.653 & 0.347 & 0.033 & 0.018 \\
\hline Amount of catches & 0.155 & 0.755 & 0.245 & 0.117 & 0.038 \\
\hline Fishing vessel resources & 0.041 & 0.627 & 0.373 & 0.026 & 0.015 \\
\hline Labor shortages & 0.029 & 0.452 & 0.548 & 0.013 & 0.016 \\
\hline Catch load capacity & 0.052 & 0.740 & 0.260 & 0.038 & 0.013 \\
\hline
\end{tabular}




\section{Conclusions}

This paper seeks to investigate factors affecting the choice of cold chain mode of transport from the perspective of Taiwanese companies operating longline tuna fishing vessels in the Indian Ocean, which are chiefly motivated by the need to reduce operating costs, and also looks at their choices of means of transport. In order of their degree of influence, the 16 chief factors affecting this decision were:

(1) fishing vessel operating location;

(2) fishing season;

(3) annual maintenance schedule;

(4) reefer ship compliance;

(5) level of transshipment costs;

(6) changes in annual catch quotas;

(7) changes in the market price of fish;

(8) reefer container vessel schedules;

(9) international management organization regulatory restrictions;

(10) effect of Regional Observer Program;

(11) reduction in fishing ground;

(12) rampant Somalian piracy;

(13) amount of catches;

(14) catch load capacity;

(15) labor shortages; and

(16) fishing vessel resources.

These factors were also the assessment criteria used by the industry to evaluate cold chain modes of transport.

Furthermore, the study found that all the experts agreed that the dimension of "Fishing vessel operating costs" was the most important consideration when choosing cold chain mode of transport, and was followed by "Fishing vessel operating efficiency," "International business environment" and finally, "Fishing business strategy." The eight assessment criteria that had a major impact on cold chain mode of transport decisions were:

(1) amount of catches;

(2) changes in the market price of fish;

(3) fishing vessel operating location;

(4) level of transshipment costs;

(5) international management organization regulatory restrictions;

(6) rampant Somalian piracy;

(7) changes in annual catch quotas; and

(8) catch load capacity.

Through an assessment of the dimensions, this study also found that reefer ships are still the preferred means of transshipping frozen catch. However, the assessment criteria "Rampant Somalian piracy," which is connected with the international environment, "Level of transshipment costs," which is connected with fishing boat operating costs, "Annual 
MABR

2,4 maintenance schedule," which is connected with vessel operating strategies, and "Labor shortages," which is connected with fishing boat operating efficiency, all tend to make reefer container ships the preferred means of transport.

As the problem of piracy cannot be solved in the short term, plus international oil prices and other relevant costs are likely to continue gradually increasing, reefer container ships will probably be increasingly used for the transshipment of frozen catch in the future. It can be recommended that reefer container ship operators should increase container volume, and should also strengthen their quality and temperature control.

Another finding of this study is that, in view of the prevailing international circumstances, the fishing industry is not as dependent on reefer ships as in the past, which is also a reflection of the increasing operating costs of the fishing industry in the Indian Ocean. It is, therefore, recommended that the government and industry associations should provide subsidies and incentives for those operators that participate in measures promoting compliance with international policies, which will enhance the competitiveness of our fishing vessels in the Indian Ocean.

\subsection{Recommendations}

5.1.1 Proposals for vessel operators. The main conclusion of this study is that "Amount of catch" and the "Changes in the market price of fish" are the two most important considerations when choosing cold chain mode of transport. Although the sustainable management strategies of international fisheries management organizations are still insufficient to compensate for the fishing capacity of boats from various countries, we can still expect that fisheries resources will slowly recover in the future.

Strategic use of mode of transport: The use of reefer container ships to transship frozen tuna can prolong transport time, which can strategically ensure that supply cannot meet demand. This will allow a break from the customary practice prevailing in the past in which reefer ships would quickly transship tuna to Japan, which often cost excessively low market fish prices.

5.1.2 Proposals for the industry association. Strategic partnerships with shipping companies: Association members can take advantage of their group bargaining power to negotiate satisfactory cooperation arrangements with container ship operators, such as by ensuring the availability sufficient quantity of containers, which will help the industry to reduce costs and address issues such as the lack of available containers.

5.1.3 Proposals for the container shipping industry. The manufacture of superior reefer container ships: While this study found that the threat of piracy was a factor motivating the choice of reefer container ships, this problem cannot be resolved in the short term. As international oil prices and other relevant costs have been gradually increasing, the use of reefer container ships to transport catch has also been increasing. We, therefore, recommend that container shipping companies increase the number of ultra-low-temperature reefer containers that can be carried on their vessels.

Improvement of the quality of in-service reefer container ships: Since the longline fishing industry has long complained about the temperature quality control of reefer container ships, reefer ships are still the preferred means of transshipping frozen catch. We recommend that shipping companies replace older reefer container ships and improve their service, which will facilitate their role in the development of cold chain logistics.

Development of seafood industry clusters: The ultra-low-temperature reefer container market is an area where container shipping companies can effectively invest. Apart from demand for ultra-low-temperature containers, the far seas fisheries industry cluster located 
at Qianzhen in Kaohsiung also has great need for general supplies and bait that can be shipped using reefer container ships.

5.1.4 Proposals concerning government policies. Strictly control of the quality of frozen tuna: Because some of the fishing boats in Taiwan have inadequate refrigeration capacity, some poor-quality products are sold to the Japanese market, which are of low prices. We, therefore, recommend that the government should limit the issuance of certificate of origin. This will impact on the whole sashimi market and maintain the competitiveness of fishing vessels in Taiwan.

Designation of a fishery logistics zone: To better leverage the advantages of Qianzhen fishing port in Kaohsiung, we recommend that government fisheries agencies and the Taiwan International Ports Corporation Ltd. establish a fishery low-temperature logistics zone where companies interested in transshipment can build ultra-low-temperature processing facilities for the purpose of re-export and the creation of added value.

Establishment of on-shore port power equipment: As over 100 fishing vessels rely on Qianzhen fishing port for supplies and maintenance, we recommend that on-shore power equipment be installed. Apart from effectively reducing air pollution and noise in the Kaohsiung area, this will enable operators to power refrigeration equipment on fishing vessels using on-shore power supplies. It will also ease the waiting time and cost of the reefer container ships.

Appropriately adjusting rules and regulations: The longline tuna industry requires a huge quantity of bait. In addition to the using domestic offshore mackerel, the industry also relies on the import of bait (such as sardines). We, therefore, recommend that fisheries agencies, customs and the Taiwan International Ports Corporation arrange for the tariff-free import of frozen bait, not for human consumption, to the port of Kaohsiung. Apart from reducing the cost of transporting frozen bait in reefer ships, this will also increase the import/export container volume at the port of Kaohsiung.

5.1.5 Proposals for academic researchers. Increased study of the cold chain logistics and seafood products: While the development of cold chain logistics is in a growing trend, and the consumption of seafood is also growing, there is little domestic literature on these areas. We, therefore, suggest that more academic researches on cold chain logistics and aquatic products should be encouraged.

5.1.6 Proposals concerning future research directions. This study takes the perspective of Taiwanese companies operating longline tuna fishing vessels in the Indian Ocean. However, it does not specifically discuss the operating situation of albacore fishing vessels in Taiwan, nor does it examine fishing vessels operating in the Pacific and Atlantic Oceans. Furthermore, a similar approach can be used to investigate the situation in the purse seine and squid fisheries.

\section{References}

Branch, A. and Stopford, M. (2013), Maritime Economics, Routledge, New York, NY.

Chen, L. and Notteboom, T. (2012), "Distribution and value added logistics in the cold chain product market with application to the role of seaports", Asian Logistics Round Table 2012 Conference (ALRT 2012), University of British Columbia (UBC), available at: http://hdl.handle.net/10067/ 987570151162165141

Chow, C.J. (1989), "Effect of package conditions on the discoloration of frozen tuna flesh", Journal of the Fisheries Society of Taiwan, Vol. 16 No. 3, pp. 203-209.

Cold Chain Association (2013), "Introduction of cool chain”, available at: http://coolchain.org/about

Dellacasa, A. (1987), "Refrigerated transport by sea", International Journal of Refrigeration, Vol. 10 No. 6, pp. 349-352.

FAO (2010), "The state of world fisheries and aquaculture”, available at: www.fao.org/home/en/
Cold supply chain of

longline tuna

365 
MABR

2,4

FAO (2012), "The state of world fisheries and aquaculture", available at: www.fao.org/home/en/

Liu, M.Y. (2011), "Difficulties and strategies for South Atlantic AA Tuna longline fishing fleet", unpublished master thesis, National University of Kaohsiung.

Haward, M. and Bergin, A. (2000), “Taiwan's distant water tuna fisheries”, Marine Policy, Vol. 24 No. 1, pp. 33-43.

Hsueh, W.J. (2004), "The study on the business strategy Indian super freezer Tuna longline fishing vessels Industry used to respond to the International Quota Pressure", unpublished master thesis, National Sun Yat-Sen University.

International Institute of Refrigeration (2008), "International dictionary of refrigeration", available at: www.iifiir.org

Kaiser, H.F. (1974), “An index of factorial simplicity”, Psychometrika, Vol. 39 No.1, pp. 31-36.

Miyake, M. (2010), Recent Developments in the Tuna Industry: Stocks, Fisheries, Management, Processing, Trade and Markets, Food and Agriculture Organization of the United Nations.

Sakai, R., Watanabe, M. and Suzuki, T. (2007), "Environmental load during the distribution of cultured tuna-comparison of frozen tuna (marine transportation) and non-frozen tuna (air transportation)", Transactions-Japan Society and Air Conditioning Engineers, Vol. 24 No. 3, p. 9.

Saaty, T.L. (1980), The Analytic Hierarchy Process, McGraw-Hill, New York, NY.

Taiwan Fisheries Agency (2016), "Fisheries statistical yearbook", available at: www.fa.gov.tw/cht/

Tsudani, T. (1998), An Illustration on Fishes from Production to Consumption Process, Seizando-Shoten Publishing, Tokyo.

Watanabe, F. (1991), A Book Stated with Tastes of the Whole Tuna Entirely: Thinking about Japanese Food, Kobunsha, Tokyo.

\section{Further reading}

Choi, J.C. (1975), Frozen Food Science, Fu Wen Books, Taiwan Tainan.

Deng, J.Y. and Tzeng, G.H. (1989), "The analytic hierarchy process: concepts, techniques and applications", Journal of the Chinese Statistical Association, Vol. 27 No. 6, pp. 5-22.

Kuo, J.C. (2003), "A construction design of the cold distribution center", Journal of Refrigeration \& Air-Conditioning Technology, Vol. 22, pp. 57-76.

Taiwan Tuna Association (2016), "Fisheries statistical yearbook", available at: www.tuna.org.tw/

For instructions on how to order reprints of this article, please visit our website:

www.emeraldgrouppublishing.com/licensing/reprints.htm

Or contact us for further details: permissions@emeraldinsight.com 